\title{
Anodic Durability of DSA-Type Positive Grids for Lead-Acid Batteries*
}

\author{
Meguru INAI**, Chiaki IWAKURA** and Hideo TAMURA**
}

\begin{abstract}
The anodic durability of DSA-type positive grids for lead-acid batteries was investigated, using $\mathrm{RuO}_{2}, \mathrm{PdO}_{x}, \mathrm{Sb}$-doped $\mathrm{SnO}_{2}, \mathrm{IrO}_{2}, \mathrm{PtO}_{x}$ and $\mathrm{AuO}_{x}$ as the oxide layer. It was found that a Sb-doped $\mathrm{SnO}_{3}$ layer is very adhesive to both the titanium base and $\beta-\mathrm{PbO}_{2}$ layer, and that the addition of oxides having the rutile-type structure and metallic conductivity, such as $\mathrm{IrO}_{2}$ and $\mathrm{RuO}_{2}$, in the Sbdoped $\mathrm{SnO}_{2}$ layer is very effective for increasing the anodic durability of the $\mathrm{Ti} / \mathrm{SnO}_{2}-\mathrm{SbO}_{x} / \beta-\mathrm{PbO}_{2}$ positive grid for lead-acid batteries.
\end{abstract}

\section{Introduction}

In our previous works ${ }^{1 \sim 3)}$, DSA-type electrodes have been applied to a positive grid in lead-acid batteries, and the DSA-type grids having the long service life and low self-discharge rate have been developed by surface treatments, such as sandblasting and chemical etching, of the titanium base. The perfomance of the latest $\mathrm{Ti}(\mathrm{ce}) / \mathrm{RuO}_{2} / \beta-\mathrm{PbO}_{2}$ grid is superior to that of the pure $\mathrm{Pb}$ grid $^{3}$. For practical use, however, the service life of the DSA-type plate must be further improved at least up to the clad type plate using the $\mathrm{Pb}-\mathrm{Sb}$ alloy grid. If the amount of $\mathrm{RuO}_{2}$ loadings on the titanium base is increased in order to improve the anodic durability of the DSA-type grid, the decrease in discharging efficiency as well as the increase in self-discharge rate of the plate would occur because of the low oxygen overvoltage of the $\mathrm{RuO}_{2}$ layer, as pointed out previously ${ }^{1,2)}$. Therefore, another approach to solve the problem is that the $\mathrm{RuO}_{2}$ layer is replaced by other oxides favorably having the same crystal structure (rutile-type) but higher oxygen overvoltage. In this work, in addition to rutile-type $\mathrm{RuO}_{2}$, $\mathrm{IrO}_{2}, \mathrm{SnO}_{2}$ and $\beta-\mathrm{PbO}_{2}$, some oxides of metals such as $\mathrm{Pd}, \mathrm{Pt}$ and $\mathrm{Au}$ were chosen as an intermediate layer coated on the titanium base

* Presented at the 19 th Battery Symposium, Tokyo, November, 1978.

** Department of Applied Chemistry, Faculty of Engineering, Osaka University (Yamadakami, Suita, Osaka)

Key roords: DSA, Positive Grid, Lead-Acid Battery, Conductive $\mathrm{SnO}_{2}$ Layer, Anodic Durability of DSA-type grids because they are well known to have the high oxygen overvoltage and to be considerably stable against anodization in sulphuric acid solution.

\section{Experimental}

The surface of the titanium base was pretreated by mechanical polishing and chemical etching, and hereinafter the pretreated titanium bases will be referred to as $\mathrm{Ti}(\mathrm{mp})$ and $\mathrm{Ti}(\mathrm{ce})$, respectively. DSA-type grids were prepared by thermal decomposition method, using aqueous solutions of $\mathrm{RuCl}_{3}, \mathrm{PdCl}_{2}, \mathrm{SnCl}_{4}\left(\mathrm{SbCl}_{3}\right), \mathrm{IrCl}_{4}$, $\mathrm{H}_{2} \mathrm{PtCl}_{6}$ and $\mathrm{H}_{2} \mathrm{AuCl}_{4}$ as a coating solution on the titanium base. The amount of oxide loadings will be indicated in parentheses in mol of metal $/ \mathrm{cm}^{2}$. In some cases, $\beta-\mathrm{PbO}_{2}$ layer $\left(5 \times 10^{-5}\right.$ mol of metal $/ \mathrm{cm}^{2}$ ) was further electrodeposited on the $\mathrm{Ti} / \mathrm{MO}_{x}$ surface to prepare the $\mathrm{Ti} / \mathrm{MO}_{x} /$ $\beta-\mathrm{PbO}_{2}$ grid. The other experimental procedures, including the electrochemical measurement, were completely the same as described in the previous papers ${ }^{2,3)}$.

\section{Results and Disscussion}

3. 1 Anodic durability of $\mathrm{Ti} / \boldsymbol{\beta}-\mathrm{PbO}_{2}$ grids

The anodic durability of the $\mathrm{Ti} / \beta-\mathrm{PbO}_{2}$ grids was examined in view of the bond-strength (adhesion) of metal-oxide $\left(\mathrm{Ti} / \beta-\mathrm{PbO}_{2}\right)$ and oxide-oxide $\mathrm{TiO}_{2} / \beta-\mathrm{PbO}_{2}$ ) interfaces. For this experiment, the titanium was chemically etched, and then thermally treated at $450^{\circ} \mathrm{C}$ in air for several minutes. Figure 1 shows the variation of potential with anodization time at 


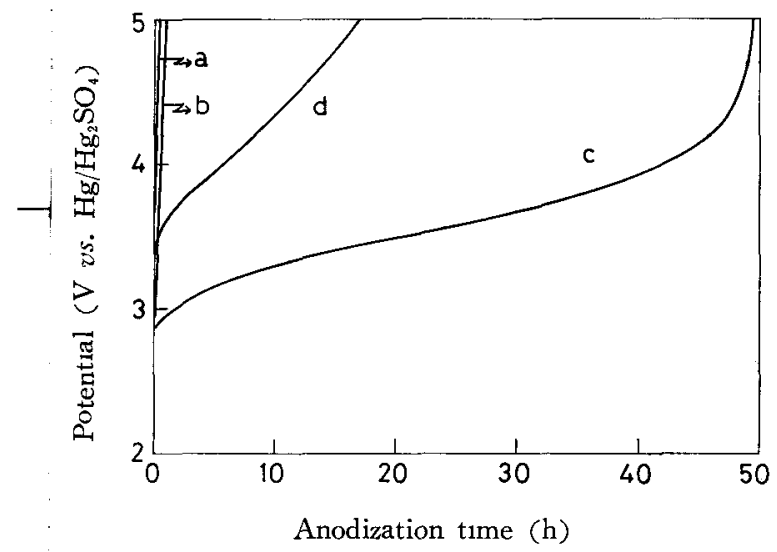

Fig. 1 Variation of potential with anodization time for $\mathrm{Ti}(\mathrm{ce}) / \beta-\mathrm{PbO}_{2}$ grids

Time of heat treatment $\left(450^{\circ} \mathrm{C}\right)$ of $\mathrm{Ti}$ base

a) $0 \mathrm{~min}$, b) $0.5 \mathrm{~min}$, c) $1 \mathrm{~min}$, d) $2 \mathrm{~min}$

$100 \mathrm{~mA} / \mathrm{cm}^{2}$ for the $\mathrm{Ti}(\mathrm{ce}) / \beta-\mathrm{PbO}_{2}$ grid. The potentials of grids (a) and (b) were rapidly raised owing to the passivation of the titanium base. On the other hand, the grid (c) whose titanium base was covered with proper amount of the thermally formed $\mathrm{TiO}_{2}$ layer revealed the longest anodic durability of all grids examined. However, the grid (d) covered with large amount of the $\mathrm{TiO}_{2}$ layer showed the more anodic potential than grid (c) did because of the additional ohmic resistance of $\mathrm{TiO}_{2}$ layer. Thus, the interface of the grids can be devided into two groups: $\mathrm{Ti}$-thin $\mathrm{TiO}_{2} / \beta-\mathrm{PbO}_{2}$ and $\mathrm{Ti}-$ thick $\mathrm{TiO}_{2} / \beta-\mathrm{PbO}_{2}$. At the latter interface, the mixed crystals or solid solutions may be easily formed since both oxides have the same crystal structure. Such formation of mixed crystals leads to the strong adhesion to each other. It can, therefore, be presumed that the oxide-oxide interface is superior to the metaloxide interface for the anodic durability.

\subsection{Anodic durability of $\mathbf{T i} / \mathrm{MO}_{x}$ grids}

The variations of potential with anodization time at $10 \mathrm{~mA} / \mathrm{cm}^{2}$ for various $\mathrm{Ti} / \mathrm{MO}_{x}$ grids are shown in Fig. 2. The anodic durability of the $\mathrm{Ti} / \mathrm{RuO}_{2}$ and $\mathrm{Ti} / \mathrm{PtO}_{x}$ grids was determined to be 15 and $125 \mathrm{~h}$, respectively. In the case of the $\mathrm{Ti} / \mathrm{AuO}_{x}$ and $\mathrm{Ti} / \mathrm{PdO}_{x}$ grids, however, the passivation of the titanium base occurred immediately after the current started to flow. It was found from the $\mathrm{X}$-ray diffraction data that the $\mathrm{MO}_{x}$ layers to these grids except for

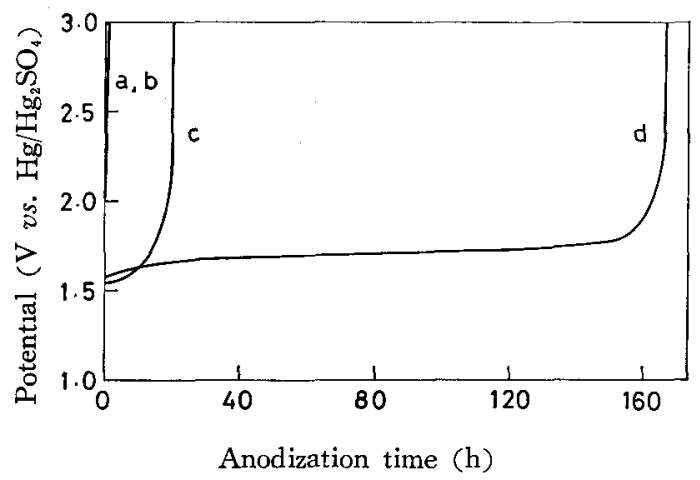

Fig. 2 Variation of potential with anodization time for $\mathrm{Ti}(\mathrm{mp}) / \mathrm{MO}_{\boldsymbol{x}}\left(10^{-7}\right)$ grids
a) $\mathrm{Ti} / \mathrm{PdO}_{x}$, b) $\mathrm{Ti} / \mathrm{AuO}_{x}$, c) $\mathrm{Ti} / \mathrm{RuO}_{2}$,
d) $\mathrm{Ti} / \mathrm{PtO} \mathrm{O}_{x}$

$\mathrm{Ti} / \mathrm{RuO}_{2}$ consisted of the mixture of oxide and metal and, in paticular, $\mathrm{AuO}_{x}$ and $\mathrm{PtO}_{x}$ were mainly composed of each metal. It is known that $\mathrm{TiO}_{2}$ formed on titanium metal by heat treatment at $450^{\circ} \mathrm{C}$ is anatase, in general. But, some workers ${ }^{4 \sim 6)}$ have clarified from the $\mathrm{X}$-ray analyses that mixed crystals of $\mathrm{TiO}_{2}$ with $\mathrm{RuO}_{2}$ having the rutile structure can be formed by thermal decomposition of mixtures of $\mathrm{TiCl}_{3}$ $\left(\mathrm{TiCl}_{4}\right)$ and $\mathrm{RuCl}_{3}$, even at $450^{\circ} \mathrm{C}$. The difference of the formation ability of mixed crystals among various oxides is probably related to the difference in dimension of the crystal lattice and in volume of the unit cell of oxide. The formation of the mixed crystals of $\mathrm{TiO}_{2}$ and $\mathrm{MO}_{x}$ was the most important factor for providing the good adhesion between the titanium base and $\mathrm{MO}_{x}$. The difference of the anodic durability of grids observed in Fig. 2 could be explained on the basis of the difference in the formation ability of mixed crystals at the grid interface: In the case of the $\mathrm{Ti} / \mathrm{AuO}_{x}$ and $\mathrm{Ti}$ / $\mathrm{PdO}_{x}$ grids, the adhesion between the titanium base and $\mathrm{MO}_{x}$ was relatively weak and the potential of these grids under the anodization was high because $\mathrm{TiO}_{2}$ and $\mathrm{MO}_{x}$ existed independently at the interface without the formation of mixed crystals. On the other hand, in the case of the $\mathrm{Ti} / \mathrm{RuO}_{2}$ and $\mathrm{Ti} / \mathrm{PtO}_{x}$ grids, the adhesion between the titanium base and $\mathrm{MO}_{x}$ was relatively strong because the mixed crystals of rutile-type $\mathrm{TiO}_{2}-\mathrm{RuO}_{2}$ and $\mathrm{TiO}_{2}-\beta-\mathrm{PtO}_{2}$ 
were formed at the grid interfaces. The mixed crystal layer of $\mathrm{TiO}_{2}-\beta-\mathrm{PtO}_{2}$ was estimated to be thinner than that of $\mathrm{RuO}_{2}$ because in the former case the main component of the $\mathrm{MO}_{x}$ layer is metallic $\mathrm{Pt}$ but not $\beta-\mathrm{PtO}_{2}$. Nevertheless, the $\mathrm{Ti} / \mathrm{PtO} \mathrm{x}_{x}$ grid showed very long service life, compared with the $\mathrm{Ti} / \mathrm{RuO}_{2}$ grid. This result indicates that the anodic durability of grids is determined not only by the formation ability of mixed crystals but also the permeability of oxygen species through the $\mathrm{MO}_{x}$ layer. In general, $\mathrm{MO}_{x}$ layer has the permeability of oxygen species because of its property of selfdiffusion of $\mathrm{O}^{2-}$ ion, as has been reported by Kavanov et $a l{ }^{\text {, }}$ for the permeability of oxygen atom through the $\beta-\mathrm{PbO}_{2}$ layer.

\section{3 Anodic durability of $\mathrm{Ti} / \mathrm{MO}_{x} / \boldsymbol{\beta}-\mathrm{PbO}_{2}$ grids}

In the following experiments, four oxides having rutile related structures, such as $\mathrm{RuO}_{2}$, $\mathrm{IrO}_{2}, \mathrm{PtO}_{x}$ and $\mathrm{SnO}_{2}$, were chosen as the $\mathrm{MO}_{x}$ layer and the anodic durability of the Ti/MO $/$ $\beta-\mathrm{PbO}_{2}$ grids was examined, inferring that the best adhesion of oxide-oxide interfaces would be achieved by using the oxides having the similar crystal structure and volume of unit cell to each other. The anodic durability and potential of various $\mathrm{Ti} / \mathrm{MO}_{x} / \beta-\mathrm{PhO}_{2}$ grids examined at $100 \mathrm{~mA} / \mathrm{cm}^{2}$ are summarized in Table 1. It is clear that the anodic durability of

Table 1 Anodic durability and potential of $\mathrm{Ti}(\mathrm{mp}) / \mathrm{MO}_{x} / \beta-\mathrm{PbO}_{2}$ grids

\begin{tabular}{|c|c|c|}
\hline Grid & $\begin{array}{l}\text { Anodic } \\
\text { durability } \\
\text { (h) }\end{array}$ & $\begin{array}{l}\text { Potential } \\
(\mathrm{V} \text { vs. } \mathrm{Hg} / \\
\left.\mathrm{Hg}_{2} \mathrm{SO}_{4}\right)\end{array}$ \\
\hline $\begin{array}{l}\mathrm{Ti} / \mathrm{SnO}_{2}\left(10^{-7}\right)-\mathrm{SbO}_{x}(1.5 \times \\
\left.10^{-9}\right) / \beta-\mathrm{PbO}_{2}\end{array}$ & 10 & 2.00 \\
\hline $\begin{array}{l}\mathrm{Ti} / \mathrm{SnO}_{2}\left(10^{-6}\right)-\mathrm{SbO}_{x}(1.5 \times \\
\left.10^{-3}\right) / \beta-\mathrm{PbO}_{2}\end{array}$ & 19 & 1.87 \\
\hline $\mathrm{Ti} / \mathrm{PtO}_{x}\left(10^{-7}\right) / \beta-\mathrm{PbO}_{2}$ & 13 & 1.90 \\
\hline $\mathrm{Ti} / \mathrm{IrO}_{2}\left(10^{-7}\right) / \beta-\mathrm{PbO}_{2}$ & 18 & 1.70 \\
\hline $\mathrm{T}_{1} / \mathrm{RuO}_{2}\left(10^{-7}\right) / \beta-\mathrm{PbO}_{2}$ & 19 & 1.78 \\
\hline
\end{tabular}

grids with $\mathrm{MO}_{x}$ loadings of $10^{-7} \mathrm{~mol}$ of metal/ $\mathrm{cm}^{2}$ increased in the order of $\mathrm{SnO}_{2}, \mathrm{IrO}_{2}$ and $\mathrm{RuO}_{2}$. Although the $\mathrm{Ti} / \mathrm{PtO}_{x}$ grid had very long anodic durability as described in the former section, the $\mathrm{Ti} / \mathrm{PtO}_{x} / \beta-\mathrm{PbO}_{2}$ grid had rather short anodic durability. This is probably due to the weak adhesion between $\mathrm{PtO}_{x}$ and $\beta-\mathrm{PbO}_{2}$, compared with the case of $\mathrm{IrO}_{2}$ and
$\mathrm{RuO}_{2}$, resulting from the fact that the $\mathrm{PtO}_{x}$ is mainly composed of metallic $\mathrm{Pt}$ as described before. On the other hand, the $\mathrm{Ti} / \mathrm{SnO}_{2}-$ $\mathrm{SbO}_{x} / \beta-\mathrm{PbO}_{2}$ grid was expected to have the longest anodic durability among these four grids because $\mathrm{SnO}_{2}$ has the volume of unit cell closest to that of $\beta-\mathrm{PbO}_{2}$, as can be seen from Table 2 in which some crystal data for $\mathrm{MO}_{2}$ compounds having rutile-related structures, extracted from ref. 8), are given. Furthermore, Laitinen and Watkins ${ }^{93}$ have studied the mech-

Table 2 Crystal data for $\mathrm{MO}_{2}$ Compounds having rutile related structures, extracted from ref. 8)

\begin{tabular}{rr|c|c|c}
\hline Oxide & \multicolumn{1}{c|}{ a } & b & \multicolumn{1}{c|}{ c } & \multicolumn{1}{c}{ V } \\
\hline $\mathrm{TiO}_{2}$ & 4.594 & - & 2.958 & 62.43 \\
$\mathrm{RuO}_{2}$ & $4.4906 \pm 2$ & - & $3.1064 \pm 2$ & 62.64 \\
$\mathrm{IrO}_{2}$ & $4.4990 \pm 2$ & - & $3.1546 \pm 2$ & 63.85 \\
$\beta-\mathrm{PtO}_{2}$ & $4.4867 \pm 4$ & $4.5366 \pm 4$ & $3.1375 \pm 5$ & 63.85 \\
$\mathrm{SnO}_{2}$ & 4.738 & - & 3.188 & 71.57 \\
$\beta-\mathrm{PbO}_{2}$ & $4.955 \pm 1$ & - & $3.383 \pm 2$ & 83.06 \\
\hline
\end{tabular}

anism of anodic deposition and cathodic stripping of $\mathrm{PbO}_{2}$ on $\mathrm{Sb}$-doped $\mathrm{SnO}_{2}$ and concluded that the first fractional monolayer of $\mathrm{PbO}_{2}$ was bonded directly to $\mathrm{SnO}_{2}$ and was different from bulk $\mathrm{PbO}_{2}$. In Table 1 , the anodic durabiilty of $\mathrm{Ti} / \mathrm{SnO}_{2}\left(10^{-\tau}\right)-\mathrm{SbO}_{x}\left(1.5 \times 10^{-9}\right) / \beta-\mathrm{PbO}_{2}$ grid is relatively short. This is attributable to the ohmic resistance at the $\mathrm{Ti} / \mathrm{SnO}_{2}$ interface. However, the $\mathrm{Ti} / \mathrm{SnO}_{2}\left(10^{-5}\right)-\mathrm{SbO}_{x}\left(1.5 \times 10^{-9}\right) /$ $\beta-\mathrm{PbO}_{2}$ grid revealed the long anodic durability comparable to the $\mathrm{Ti} / \mathrm{RuO} \mathrm{O}_{2} / \beta-\mathrm{PbO}_{2}$ grid. In order to reduce the ohmic resistance of $\mathrm{Sb}_{-}$ doped $\mathrm{SnO}_{2}$ bulk layer, some oxides with metallic conductivity, such as $\mathrm{PtO}_{x}, \mathrm{IrO}_{2}$ and $\mathrm{RuO}_{2}$, were added in the Sb-doped $\mathrm{SnO}_{2}$ layer. The $\mathrm{Ti} / \mathrm{SnO}_{2}-\mathrm{SbO}_{x}-\mathrm{MO}_{x} / \beta-\mathrm{PbO}_{2}$ grids were examined at $100 \mathrm{~mA} / \mathrm{cm}^{2}$. The anodic durability of grids increased in the order of $\mathrm{SnO}_{2}-\mathrm{PtO}_{x}$, $\mathrm{SnO}_{2}-\mathrm{IrO}_{2}$ and $\mathrm{SnO}_{2}-\mathrm{RuO}_{2}$. The experimental anodic durability and potential are' summarized in Table 3. The anodic durability of the Ti/ $\mathrm{SnO}_{2}-\mathrm{SbO}_{x} / \beta-\mathrm{PbO}_{2}$ grid was greatly extented by coexistance of $\mathrm{RuO}_{2}$ or $\mathrm{IrO}_{2}$ in the $\mathrm{Sb}$-doped $\mathrm{SuO}_{2}$ layer. Furthermore, it should be noted that the relative values for these grids corresponded to those for the $\mathrm{Ti} / \mathrm{MO}_{x} / \beta-\mathrm{PbO}_{2}$ grids except for the $\mathrm{PtO}_{x}$ containing grids. In the 
Table 3 Anodic durability and potential of $\mathrm{Ti}(\mathrm{mp}) / \mathrm{SnO}_{2}-\mathrm{SbO}_{x}-\mathrm{MO}_{x} / \beta-$ $\mathrm{PbO}_{2}$ grids

\begin{tabular}{c|c|c}
\hline \hline Grid & $\begin{array}{c}\text { Anodic } \\
\text { durability } \\
(\mathrm{h})\end{array}$ & $\begin{array}{c}\text { Potential } \\
(\mathrm{V} \text { vs. } \mathrm{Hg} /\end{array}$ \\
\hline $\left.\mathrm{Hg}_{2} \mathrm{SO}_{4}\right)$
\end{tabular}

case of the $\mathrm{Ti} / \mathrm{SnO}_{2}-\mathrm{SbO}_{x}-\mathrm{PtO}_{x} / \beta-\mathrm{PbO}_{2}$ grid, an addition effect of $\mathrm{PtO}_{x}$ was not significant, and the anodic durability was apploximately equal to the algebraic sum of the anodic durability of the $\mathrm{Ti} / \mathrm{SnO}_{2}-\mathrm{SbO}_{x} / \beta-\mathrm{PbO}_{2}$ and $\mathrm{Ti} /$ $\mathrm{PtO}_{x} / \beta-\mathrm{PbO}_{2}$ grids. This is probably due to the partial isolation of $\mathrm{PtO}_{x}$ from $\mathrm{Sb}$-doped $\mathrm{SnO}_{2}$.

The dependence of the anodic durability of the $\mathrm{Ti}(\mathrm{mp}) / \mathrm{SnO}_{2}-\mathrm{SbO}_{x}-\mathrm{IrO}_{2}\left(10^{-7}\right) / \beta-\mathrm{PbO}_{2}$ grid on the amount of $\mathrm{SnO}_{2}$ loadings was examined. For the comparison, the anodic durability of the $\mathrm{Ti}(\mathrm{mp}) / \mathrm{RuO}_{2}\left(10^{-5}\right)$ electrode in brine electrolysis was also examined under the same conditions. Figure 3 shows the variation of potential with anodization time at $100 \mathrm{~mA} / \mathrm{cm}^{2}$.

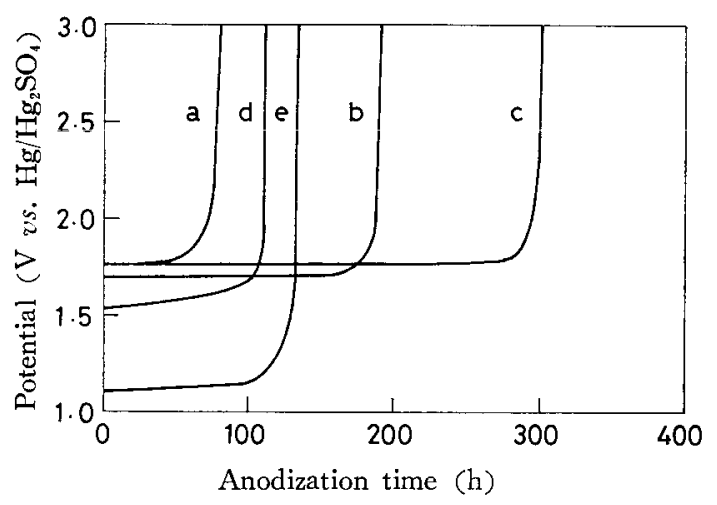

Fig. 3 Variation of potential with anodization time

a) $\mathrm{Ti}(\mathrm{mp}) / \mathrm{SnO}_{2}\left(10^{-7}\right)-\mathrm{SbO}_{x}\left(1.5 \times 10^{-9}\right)$ $\mathrm{IrO}_{2}\left(10^{-7}\right) / \beta-\mathrm{PbO}_{2}$

b) $\mathrm{Ti}(\mathrm{mp}) / \mathrm{SnO}_{2}\left(10^{-6}\right)-\mathrm{SbO}_{x}\left(1.5 \times 10^{-8}\right)-$ $\mathrm{IrO}_{2}\left(10^{-7}\right) / \beta-\mathrm{PbO}_{2}$

c) $\mathrm{Ti}(\mathrm{mp}) / \mathrm{SnO}_{2}\left(10^{-5}\right)-\mathrm{SbO}_{x}\left(1.5 \times 10^{-7}\right)-$ $\mathrm{IrO}_{2}\left(10^{-7}\right) / \beta-\mathrm{PbO}_{2}$

d ) $\mathrm{Ti}(\mathrm{mp}) / \mathrm{SnO}_{2}\left(10^{-6}\right)-\mathrm{SbO}_{x}\left(1.5 \times 10^{-8}\right)-$ $\mathrm{IrO}_{2}\left(10^{-7}\right)$

e) $\mathrm{Ti}(\mathrm{mp}) / \mathrm{RuO}_{2}\left(10^{-5}\right)$
The anodic durability of the $\mathrm{Ti} / \mathrm{SnO}_{2}-\mathrm{SbO}_{x^{-}}$ $\mathrm{IrO}_{2} / \beta-\mathrm{PbO}_{2}$ grid increased with increasing amount of $\mathrm{SnO}_{2}$ loadings but the potential was the lowest at $10^{-6} \mathrm{~mol}$ of metal $/ \mathrm{cm}^{2}$. The anodic durability of the $\mathrm{Ti}(\mathrm{mp}) / \mathrm{SnO}_{2}\left(10^{-5}\right)-\mathrm{SbO}_{x}(1.5 \times$ $\left.10^{-7}\right)-\mathrm{IrO}_{2}\left(10^{-7}\right) / \beta-\mathrm{PbO}_{2}$ grid was 2 times that of the $\mathrm{Ti}(\mathrm{mp}) / \mathrm{RuO}_{2}\left(10^{-5}\right)$ electrode and was about 20 times that of the $\mathrm{Ti}(\mathrm{mp}) / \mathrm{RuO}_{2}\left(10^{-7}\right) /$ $\beta-\mathrm{PbO}_{2}$ grid $^{2)}$. The anodic durability of this grid can be further increased by the surface treatment of titanium base and the service life of the $\mathrm{Ti}$ (ce) $/ \mathrm{SnO}_{2}-\mathrm{SbO}_{\boldsymbol{x}}-\mathrm{IrO}_{2}$ or $\mathrm{RuO}_{2} / \beta-\mathrm{PbO}_{2} /$ paste plate seems to be some thousand cycles, according to the speculation from the relationship of the DSA-type plate and grid $^{3)}$. It was therefore considered that the $\mathrm{Ti}(\mathrm{ce}) / \mathrm{SnO}_{2}-$ $\mathrm{SbO}_{x}-\mathrm{IrO}_{2}$ or $\mathrm{RuO}_{2} / \beta-\mathrm{PbO}_{2}$ grid as a positive grid in lead-acid batteries had the sufficient anodic durability for the practical use.

In order to prove the reason for very long anodic durability of the $\mathrm{Ti} / \mathrm{SnO}_{2}-\mathrm{SbO}_{x}-\mathrm{IrO}_{2} / \beta-$ $\mathrm{PbO}_{2}$ grid, the surface and cross section morphologys of the $\mathrm{Ti} / \mathrm{SnO}_{2}-\mathrm{SbO}_{x}-\mathrm{IrO}_{2}$ and $\mathrm{Ti} /$ $\mathrm{RuO}_{2}$ grids were examined by means of a scanning electron microscope (SEM). Microphotographs taken by SEM of the surface of these grids are shown in Fig. 4. The surface of the $\mathrm{SnO}_{2}-\mathrm{SbO}_{x}-\mathrm{IrO}_{2}$ was very smooth, whereas the surface of the $\mathrm{RuO}_{2}$ had large cracks. As can

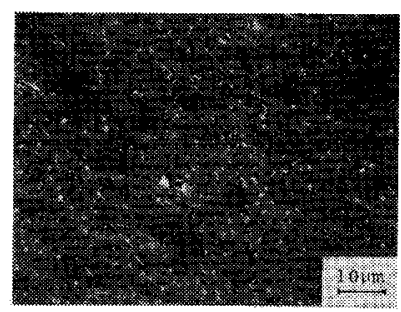

$\mathrm{Ti} / \mathrm{SnO}_{2}-\mathrm{SbO}_{x}-\mathrm{IrO}_{2}$

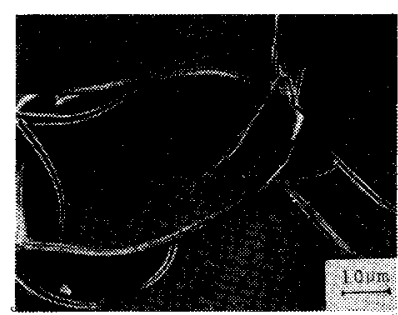

$\mathrm{Ti} / \mathrm{RuO}_{2}$

Fig. 4 Microphotographs taken by SEM of surface of $\mathrm{Ti}(\mathrm{mp}) / \mathrm{SnO}_{2}\left(10^{-5}\right)$ $\mathrm{SbO}_{x}\left(1.5 \times 10^{-7}\right)-\operatorname{IrO}_{2}\left(10^{-7}\right)$ and $\mathrm{Ti}(\mathrm{mp}) / \mathrm{RuO}_{2}\left(10^{-5}\right)$ grids 


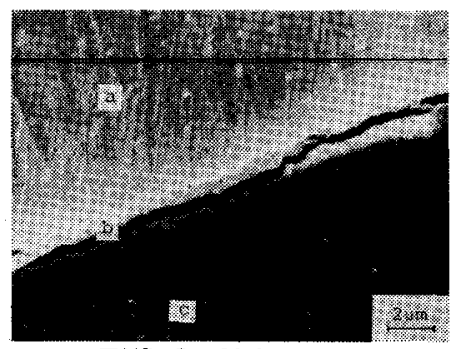

$\mathrm{Ti} / \mathrm{SnO}_{2}-\mathrm{SbO}_{x}-\mathrm{IrO}_{2}$

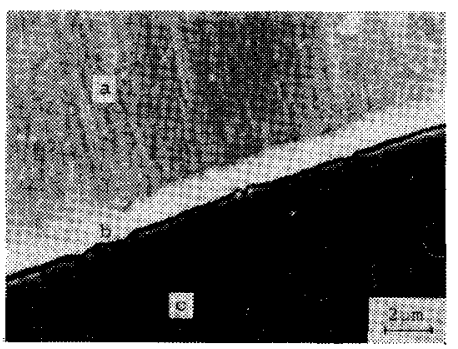

$\mathrm{Ti} / \mathrm{RuO}_{2}$

Fig. 5 Microphotographs taken by SEM of cross section of $\mathrm{Ti}(\mathrm{mp}) /$ $\mathrm{SnO}_{2}\left(10^{-5}\right)-\mathrm{SbO}_{x}\left(1.5 \times 10^{-7}\right)-\mathrm{IrO}_{2}$ $\left(10^{-7}\right)$ and $\mathrm{Ti}(\mathrm{mp}) / \mathrm{RuO}_{2}\left(10^{-5}\right)$ grids

a) Ti base,b) Oxide layer, c) Epoxy resin

be seen from Fig. 5, the thickness of $\mathrm{SnO}_{2}-$ $\mathrm{SbO}_{x}-\mathrm{IrO}_{2}$ and $\mathrm{RuO}_{2}$ layers was $0.6 \sim 1 \mu \mathrm{m}$ and $1.2-1.4 \mu \mathrm{m}$, respectively. The $\mathrm{SnO}_{2}-\mathrm{SbO}_{x}-\mathrm{IrO}_{2}$ layer was considered to be made up of very dense layer by increasing the density and the contraction of crystal lattice, as have been reported by Matsushita and Yamai ${ }^{10)}$. Such smooth surface and dence layer are fairly effective for retarding the passivation of the titanium base.
From the above results, it was clarified that the $\mathrm{Sb}$-doped $\mathrm{SnO}_{2}$ 'layer is very adhesive to both the titanium base and $\beta-\mathrm{PbO}_{2}$ layer 'and that the addition of the oxides having the rutile-type structure and metallic conductivity, such as $\mathrm{IrO}_{2}$ and $\mathrm{RuO}_{2}$, in the Sb-doped $\mathrm{SnO}_{2}$ layer is very effective for increasing the anodic durability of $\mathrm{Ti} / \mathrm{SnO}_{2}-\mathrm{SbO}_{x} / \beta-\mathrm{PbO}_{2}$ grid. In conclusion, it was proved that the $\mathrm{Ti} / \mathrm{SnO}_{x^{-}}$ $\mathrm{SbO}_{x}-\mathrm{MO}_{x} / \beta-\mathrm{PbO}_{2}$ grids have a bright prospect of developing the new field of application as a positive grid in lead-acid batteries.

Acknowledgement :

The authors express appreciation to Yuasa Battery Co. Ltd. for taking the microphotographs of SEM. $<$ E578>(Received Feb. 27, 1979)

\section{References :}

1) C. Iwakura, M. Inai and H. Tamura, Chem. Lett. (1977), 1407.

2) M. Inai, C. Iwakura and H. Tamura, J. Appl. Electrochem. 8, 515 (1978).

3) M. Inai, C. Iwakura and H. Tamura, J. Appl. Electrochem. in press.

4) I.E. Veselovskaya, E.K. Spasskaya, V.A. Sokolov, V.I. Tkachenko and L.M. Yakimenko, Élektrokhimiya 1070 (1974).

5) F. Hine, M. Yasuda and T. Yoshida, J. Electrochem. Soc. 124, 500 (1977).

6) K. Fukuda, C. Iwakura and H. Tamura, Electrochim. Acta, in press.

7) B.N. Kavanov, E.S. Weisberg, I.L. Romanova and E.V. Krivolapova, Electrochim. Acta 9, 1197 (1964).

8) D.B. Rogers, R.D. Shannon, A.W. Sleight and J.L.Gillson, Inorg. Chem. 8841 (1969).

9) H.A. Laitinen and N.H. Watkins, J. Electrochem. Soc. 123, 804 (1976).

10) T. Matsushita and I. Yamai, Yogyo Kyokaishi 80, 305 (1972). 